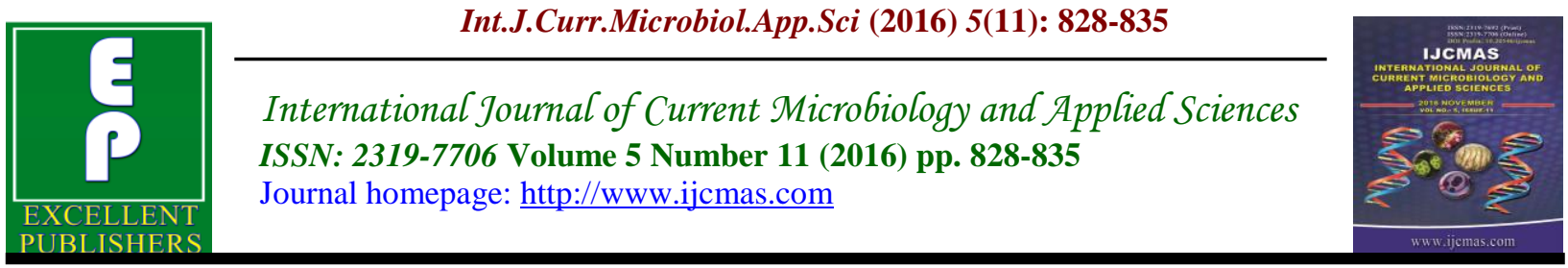

Original Research Article

http://dx.doi.org/10.20546/ijcmas.2016.511.094

\title{
Preparation and Evaluation of Bacteriophage Lysate Specific for Salmonella typhimurium
}

\author{
Adeela Iqbal*, M. Shafi Hasni, Sajjad-ur-Rahman, Rizwan Aslam and Kasib Khan \\ University of Agriculture, Faisalabad, Pakistan \\ *Corresponding author
}

\begin{abstract}
A B S T R A C T
Keywords

S. typhimurium, Salmonellosis, bacteriophages, Hardy Chrome SS agar.

Article Info

Accepted:

28 August 2016

Available Online:

10 September 2016

Salmonella is Gram negative, rod-shaped bacteria S. typhimurium not only infects the humans but also infects the animal and poultry. Phage therapy is a method of treatment in which viruses are used to lyses the bacteria. The aim of this study was growth of bacteriophages against $S$. typhimurium. 26 samples were collected from University of Agriculture Faisalabad out of which 5 samples were from poultry droppings, 5samples were from cow fecal, 6 stool samples were from cat, 5 stool samples were from sheep and horse. When these samples were cultured in Tetrathionate broth 21 samples showed turbidity. These 21 samples were cultured on Salmonella Shigella agar. 18samples showed colorless colonies on SS agar. These colonies were further streaked on Hardy CHROME SS agar after 24h incubation at $37^{\circ} \mathrm{C}$ large black and clear center colonies appeared on this media. Sewage water contains abundant S.Typhimurium serves as vulnerable and extremely flexible host for the development of phages, so 5 sewage water samples were collected. The plaque caused by the phages varies in size and is characterized by spherical zone. The number of PFU from phage lysate was ranging from $10^{5}$ ${ }^{\times} 10^{6} \mathrm{pfu} / \mathrm{ml}$.
\end{abstract}

\section{Introduction}

Salmonella is rod shaped bacteria and their length is about 20 to $50 \mathrm{um}$ and their width is about 7 to $15 \mathrm{um}$. Salmonella appear as gram negative bacteria under bacteriologic staining. They are facultative anaerobe and anaerobe and their ability to reproduce is best at room temperature, therefore they cause food intoxication (Özkalp, 2012).

S. typhimurium is the cause of food poisoning all over the world (Mmolawa et al., 2001). Salmonellosis is a disease condition caused by a large group of bacteria of the genus Salmonella that can affect human beings throughout the world. Salmonella infection remains as a serious problem in the public health significance worldwide and causes large economic loss resulting from mortality, morbidity and poor growth with the hazard of transmitting food poisoning with gastroenteritis to human and represents a serious problem for the food industry.

In the public health area Salmonella is a worldwide issue. People most at risk for serious problems due to Salmonella food intoxication include children, adults, 
pregnant women and people who have compromised immune systems. Salmonellosis is marked clinically in all hosts by one of three major syndromes acute enteritis or chronic enteritis, per acute systemic infection. Symptoms usually include nausea, headache, fatigue, vomiting, abdominal pain,gastroenteritis, and bloody diarrhea with mucus (Nesa et al., 2011).

A temperate bacteriophage of family Podoviridae (P22) phage has interactions with S. typhimurium and it belongs to family Podoviridae. It is double stranded DNA phage with icosahedra procapsid head. O antigen present in the lipopolysaccharides (LPS) of Salmonella outer membrane works as a primary receptor for P22 (Jin et al., 2015).

E. coli $\mathrm{O} 157: \mathrm{H} 7$ is food born pathogen which causes infection. A phage against E.coli $\mathrm{O} 157: \mathrm{H} 7$ strain is FAHEc1 it has icosahedra head. It is a tailed phage which belongs to family myoviridae (Hudson, 2013).

Phages are viruses that infect bacteria for their existence (Rahaman et al., 2014). British pathologists in London in 1915 discover the bacteriophages by an infectious agent of Micrococcus colonies (Tan et al., 2008). In 1910 the bacteriophage phenomenon is first seen by Felix d' Herelle a French-Canadian microbiologist during study the microbiologic methods of managing the locusts in Mexico (Golkar et al., 2013). Phages are highly host specific and they only attack a particular group of bacteria species. The host specificity is dependent on the development of detection system of the viruses, based on lock and-key theory (Sulakvelidze et al., 2001).

The receptors on the bacterial host are identified by the protein on the phage (Tan et al., 2008). It is expected that there are a number of phages than any other organism in the world. In biosphere the phages are present everywhere and the number of phages directly proportional to the number of bacterial hosts. According to estimation in coastal sea water and fresh water, there are $10^{6}$ and $10^{9}$ tailed phages present respectively. There are minimum 12 different groups of phages present and every phage is specific to its bacterial host. The lytic and lysogenic are two main types of phages. Bacterial host attacked by lytic phages replicate themselves swiftly and rupture the host cell. Lysogenic phages penetrate their genetic material into the host DNA. Therefore, lytic phages are mostly used to kill the bacteria. Bacteriophages reduce the chances of secondary infections because they are specific to their bacterial host so they can easily kill the microorganisms (Angela, 2006).

On the other hand antibiotics cause the secondary infections because they affect the pathogens and normal flora of patients. At the site of infection bacteriophage replicated and lyses the pathogen which caused infection on the other hand antibiotics not only affect the pathogens which cause the infection but also move through the body. Phage treatment has no side effects, but antibiotic treatment cause allergy and secondary infections (Golkar et al., 2013).

\section{Materials and Methods}

\section{Sample collection}

26 samples were collected from University of Agriculture Faisalabad out of which 5 samples were from poultry droppings, 5 samples were from cow fecal, 6 stool samples were from cat, 5 stool samples were from sheep and horse. Collected samples were analyzed for the presence of $S$. typhimurium. The Samples were cultured on Salmonella Shigella agar for isolation of 
Salmonella. Then for isolation of $S$. typhimurium it was again cultured on Hardy CHROME SS agar. The colonies grown on plates were Gram stained and for further confirmation hemolysis, Catalase and coagulase test was performed.

\section{Bacteriophage collection and isolation}

6 sewage samples were collected and centrifuged at $10,000 \times g$ for $10 \mathrm{~min}$ to remove solid particles and then filtered with $0.22 \mu \mathrm{m}$ pore syringe filters. For enrichment, isolation and purification of bacteriophages, modified methods were used. Salmonella grows overnight at $37^{\circ} \mathrm{C}$ in NB to obtain pure bacterial cultures. $0.1 \mathrm{~mL}$ of overnight pure cultures of Salmonella was inoculated into $10 \mathrm{~mL}$ NB and incubated at $37{ }^{\circ} \mathrm{C}$ shaker for $3 \mathrm{~h}$ to grow exponential phase cultures. Filter sample supernatant $(4.5 \mathrm{~mL})$ was then mixed with $0.5 \mathrm{~mL}$ exponential phase bacterial cultures and $0.5 \mathrm{~mL} 10 \times$ concentrated NB and was incubated at $37^{\circ} \mathrm{C}$ for $24 \mathrm{~h}$. After incubation samples were centrifuged at $10,000 \times g$ for $10 \mathrm{~min}$, supernatants was filtered with a $0.22 \mu \mathrm{m}$ filter syringe and was used as enriched phage (EP) samples (Akhtar et al., 2014).

\section{Plaque assay}

For plaque assay, a series of 10-fold dilutions were made. Pipette $0.9 \mathrm{ml}$ of sterile PBS in tubes and then transfers $0.1 \mathrm{ml}$ of the phage suspension into tube 1 and mix it. Using the same pipette, transfer $0.1 \mathrm{ml}$ from tube 1 to tube 2 and mix it and so on. A single colony of overnight culture of $S$. typhimurium was inoculated into $5 \mathrm{ml}$ of LB broth and incubated at $37{ }^{\circ} \mathrm{C}$ for 3 hours. Top agarose was aliquoted $(3 \mathrm{ml})$ into tubes placed at $45{ }^{\circ} \mathrm{C}$ in a water bath. $0.1 \mathrm{ml}$ phage and $0.5 \mathrm{ml} S$. typhimurium cells were added to the top agarose medium mixed and poured onto a nutrient agar plate. The plates were allowed to cool and incubated overnight at $37{ }^{\circ} \mathrm{C}$. Plaques were observed, counted and the amount of phage was determined as plaque forming unit (Akhtar et al., 2014).

\section{Results and Discussion}

26 samples were cultured in Tetrathionate broth out of which 21 samples 21 samples showed turbidity after 24 hours incubation at $37^{\circ} \mathrm{C}$. Then these 21 samples were cultured on Salmonella Shigella agar. On SS agar 18 samples appeared colorless colonies. Colonies were checked for their size, shape, margin and elevation macroscopically. Then these colonies were further streaked on Hardy CHROME SS agar. 18 samples appeared with clear black colonies in form of beadson Hardy CHROME SS agar (Table 1). With specific number of identification culture plates were marked. Some biochemical tests Indole, methyl red test and Voges Proskauer were performed.H2S production was also seen which was positive. Triple sugar iron test was performed for confirmation of $S$. typhimurium. Out of twenty six samples nineteen samples were positive for methyl red, eighteen samples were negative for Voges Proskauer, eighteen samples were negative for indole, eighteen samples were positive for $\mathrm{H} 2 \mathrm{~S}$, citrate and Catalase (Table 2).

S. typhimurium is present in excess in sewage water, which provides adjustable host for the development of phages. Through bacteriophages isolation protocol phage lysate was isolated and plaque assay was performed to confirm the phage titer. Six sewage water samples were collected for isolation of phage lysate specific for $S$. typhimurium. The morphology of single plaque varies in size.

The Plaque caused by the phages varies in size and is characterized by the spherical 
zone .The number of PFU from phage lysate were ranging from $1 \times 10^{5}$ to $1 \times 10^{6} \mathrm{pfu} / \mathrm{ml}$ (Table 3)

The purpose of this study was to prepare specific phage lysate for $S$. typhimurium from sewage water because sewage water contains a lot of bacteriophages. $S$. typhimurium was isolated from fecal samples of different animals and from poultry. High occurrence of S. typhimurium was present in poultry. S. typhimurium cause salmonellosis in poultry and cause serious problem worldwide (Khan et al., 2007). When food and water are contaminated with stool or direct fecal oral route food borne illness among the people and transmission can occur. An important reservoir of Salmonellaserovar is the human stool that is grouping of micro- organisms based on their cell surface antigen (Kumar et al., 2009). The significance of Salmonellosis in public health sector is a growing anxiety day by day throughout the world and over the last several decades there have been significant shift predominant Salmonella serovars associated with human infections (Nesa et al., 2011). In the past Salmonellosis cause huge loss to society in many countries around the world. Annually two to four million cases have been reported and yet a significant number of cases have been unreported worldwide. The main cause of food borne illness is non-typhoid Salmonella and in Bangladesh (ICDDR, B) its increasing antimicrobial resistance is associated with high risk of hospitalization (Salam et al., 2003). In Bangladesh 66\% cases of food borne illness is due to non typhi Salmonella. In 1998 highest proportion (15\%) was isolated and in 1995 it was less than 10\% for other years (Nesa et al., 2011). $S$. typhimurium is a zoonotic pathogen which is transmitted through contaminated drink and food through direct and indirect contacts with infected pets and from person to person or contaminated materials (Anonymous, 2012; Cavallaro et al., 2011; Centers for Disease Control and Prevention, 2010). S. typhimurium has a broad host range and is known to cause disease in humans, live stock, domestic fowl, rodents and birds (Chen et al., 2010; Lawson et al., 2011; Rabsch et al., 2002).

26 samples were collected out of which 5 cow fecal samples, 6 stool samples from cat, 5 stool samples from sheep, horse and 5 poultry dropping samples. These samples were cultured in Tetrathionate broth out of twenty six samples twenty one samples showed turbidity in Tetrathionate broth. Eighteen samples showed colorless colonies on Salmonella Shigella agar. On Hardy CHROME SS Agar eighteen samples showed pure black colonies. For further confirmation biochemical tests were performed. Results of biochemical test are shown in table 2 .

In May 7, 2013 total of 146 persons infected with the outbreak strain of Salmonella typhimurium ( $S$. typhimurium) have been reported from 26 states the Center for Disease Control and Prevention has estimated the most predominant isolated organisms in most $S$. typhimurium cases associated with the consumption of contaminated poultry, pork and beefproduct. Salmonella enteric serotypes Enteritidis and Typhimurium. One hundred samples of retail raw chicken meat andgiblets (Liver, heart and gizzard) which were collected. $S$. typhimurium was detected at rate of $44 \%$, $40 \%$ and $48 \%$ in chicken meat, liver and heart (El-Aziz, 2013).

Eggplant fruit or aubergine (Solanumm elongena), is used worldwide as an ingredient in a variety of foods and is consumed as an appetizer. One of the most popular appetizer dishes in the world 
Eggplant dip, known as meatball in Jordan (Panagou et al., 2013).In Turkish restaurant and in Australia in 2005 eggplant consumption was responsible for a Salmonella typhimurium outbreak (Gregory, 2005).

The most important food-borne diseases worldwide is Salmonellosis and its outbreaks commonly result from consumption of food contaminated by Salmonella. In 2013 according to the report published by European Food Safety
Authority, Salmonellosis was still the most commonly reported zoonosis, with 82,694 confirmed human cases and 59 reported deaths in the EU (Wang et al., 2016).

In the collection accounting for $71 \%$ (164/232) of all Salmonella isolates Salmonella typhimurium was the predominant serovar. The second most prevalent serovar was $S$. enteritidis with $8 \%$ of all isolates.S. typhimurium accounts for over $60 \%$ of all cases Salmonella- associated diarrhea in horses (Duijkeren et al., 2002).

Table.1 Results of culture isolates recovered from fecal specimen on the basis of cultural and morphological characteristics

\begin{tabular}{|l|l|l|l|l|l|}
\hline Fecal sample & Sample size & $\begin{array}{l}\text { Gram negative } \\
\text { coco bacilli and } \\
\text { motile }\end{array}$ & $\begin{array}{l}\text { Colorless } \\
\text { colonies with } \\
\text { black centered } \\
\text { on SS agar }\end{array}$ & $\begin{array}{l}\text { Pure black } \\
\text { colonies on Hardy } \\
\text { CHROME SS } \\
\text { Agar }\end{array}$ & $\begin{array}{l}\text { Turbidity } \\
\text { In Tetrathionate } \\
\text { broth }\end{array}$ \\
\hline Poultry & 5 & 4 & 4 & 4 & 4 \\
\hline Cow & 5 & 3 & 3 & 3 & 4 \\
\hline Cat & 6 & 4 & 4 & 4 & 5 \\
\hline Sheep & 5 & 3 & 3 & 3 & 4 \\
\hline Horse & 5 & 4 & 4 & 4 & 4 \\
\hline Total & 26 & 18 & 18 & 18 & 21 \\
\hline
\end{tabular}

Table.2 Results of Biochemical test on culture isolates of Salmonella spp. recovered from fecal, stool and poultry dropping samples

\begin{tabular}{|l|l|l|l|l|l|l|l|}
\hline $\begin{array}{l}\text { Fecal } \\
\text { Sample }\end{array}$ & $\begin{array}{l}\text { Sample } \\
\text { size }\end{array}$ & $\begin{array}{l}\text { Methyl } \\
\text { red (+) }\end{array}$ & $\begin{array}{l}\text { Voges } \\
\text { Proskauer }(-)\end{array}$ & $\begin{array}{l}\text { Indole } \\
(-)\end{array}$ & $\mathbf{H}_{2} \mathbf{S}(+)$ & $\begin{array}{l}\text { Citrate } \\
(+)\end{array}$ & $\begin{array}{l}\text { Catalase } \\
(+)\end{array}$ \\
\hline Poultry & 5 & 4 & 4 & 4 & 4 & 4 & 4 \\
\hline Cow & 5 & 3 & 3 & 3 & 3 & 3 & 3 \\
\hline Cat & 6 & 5 & 4 & 4 & 4 & 4 & 4 \\
\hline Sheep & 5 & 3 & 3 & 3 & 3 & 3 & 3 \\
\hline Horse & 5 & 4 & 4 & 4 & 4 & 4 & 4 \\
\hline Total & 26 & 19 & 18 & 18 & 18 & 18 & 18 \\
\hline
\end{tabular}


Table.3 Results of Phage Titer calculation obtained from sewage water

\begin{tabular}{|l|l|l|l|l|l|}
\hline Sample No. & $\begin{array}{l}\text { Volume of phage } \\
\text { plated(ml) }\end{array}$ & Dilution Factor & $\begin{array}{l}\text { Average no of } \\
\text { plaques }\end{array}$ & $\begin{array}{l}\text { Total no. of } \\
\text { Phages (PFU/ml) }\end{array}$ & $\begin{array}{l}\text { Plaque } \\
\text { size }(\mathrm{cm}) 11\end{array}$ \\
\hline 1 & 0.1 & $10^{3}$ & 43 & $4.3 \times 10^{5}$ & $(0.1 \pm 0.3)$ \\
\hline 2 & 0.1 & $10^{2}$ & 50 & $5.0 \times 10^{4}$ & $(0.2 \pm 0.4)$ \\
\hline 3 & 0.1 & $10^{3}$ & 30 & $3.0 \times 10^{6}$ & $(0.2 \pm 0.3)$ \\
\hline 4 & 0.1 & $10^{4}$ & 54 & $5.4 \times 10^{6}$ & $(0.2 \pm 0.3)$ \\
\hline 5 & 0.1 & $10^{2}$ & 50 & $5.0 \times 10^{4}$ & $(0.1 \pm 0.3)$ \\
\hline
\end{tabular}

In France, S. typhimurium are also the predominant serovars in animals and humans, accounting together for over $80 \%$ isolated of the Salmonellae isolated (Breuil et al., 2000).

PFU numbers from phage isolates were found to be as high as $10^{5}-10^{6} \mathrm{pfu} / \mathrm{ml}$. The overnight culture of $S$. typhimurium used in the research which provided overnight growing cells resulting in low production of progenies by the phages results the low PFU observed in this study.

By using a broth or agar - plate method the propagation at required intervals, phage filtrates of high titer were maintained. Techniques used for propagation of phage on agar plates and in broth and for phage titration and typing were as previously (Williams and Rippon, 1952).

Bacteriophages are the viruses that lyse the bacteria. Lytic phages multiplied inside the host cell. Lytic phages undergo the lytic infection cycle where they proliferated in the host cells and come out from host cells by lying procedure. Bacteriophages were faster to the bacterium cell wall throughout the progression and insert their DNA into the cell (Singleton, 1992). DNA phage and genetic material was replicated by using the host machinery and in this way encoding protein coat was transcribed systematically. Many viruses had been produced and the Salmonella Typhimurium was burst towards the end of the cycle (Akhtar et al., 2014). In contrast lysogenic phages incorporate their genetic material into the chromosomal DNA of the host or establishing themselves like a plasmid and come into the host cells in a non toxic situation. Phages tend to be more successful than antibiotics where there was a biofilm covered by a polysaccharide layer, which antibiotics typically cannot penetrate (Prescott et al., 2005). Sewage water contains abundant $S$. typhimurium which serves as vulnerable and extremely adaptable host for the development of phages,so 5 sewage water samples were collected. The plaque caused by the phages varies in size and is characterized by spherical zone. The number of PFU from bacteriophages lysate was ranging from $10^{5} \times 10^{6} \mathrm{pfu} / \mathrm{ml}$.

\section{References}

Akhtar, M., S. Viazis and F. Diez-Gonzalez. 2014. Isolation, identification and characterization of lytic, wide host range bacteriophages from waste effluents against Salmonella enteric serovars. J. Food Cntr., 38: 67-74.

Angela, C. 2006. Bacteriophage for the elimination of methicillin resistant Staphylococcus aureus (MRSA) colonization and infection. Uni of South Florida Scholar Commons.

Breuil, J., A. Brisabois, I. Casin, L. ArmandLefèvre, S. Frémy. and E. Collatz. 2000. Antibiotic resistance in 
salmonellae isolated from humans and animals in France: comparative data from 1994 and 1997.J. antimicro. Chemo., 46(6): 965-971.

Cavallaro, E., K. Date, C. Medus, S. Meyer, B. Miller, C. Kim, and J. Flint. 2011.

CDC. 2001. Outbreaks of multidrug resistant Salmonella Typhimurium associated with veterinary facilitiesIdaho, Minnesota and Washionton. Centers for Disease Control and Prevention.

Chen, J., L. Zhang, G.C. Paoli, C. Shi, S.I. Tu and X. Shi. 2010. A real-time PCR method for the detection of Salmonella enterica from food using a target sequence identified by comparative, 365 (7): 601-610.

Duijkeren, E., Van, W.J.B. Wannet, D.J. Houwers, and W. Van Pelt. 2002. Serotype and phage type distribution of salmonella strains isolated from humans, cattle , pigs , and chickens in the netherlands from 1984 to 2001 serotype and phage type distribution of salmonella strains isolated from humans, cattle, pigs, and chick. $J$. Trop. Biomed., 40(11): 3980-3985.

El-Aziz， D.M.A. 2013. Detection of Salmonella typhimurium in retail chicken meat and chicken giblets. $J$. Trop. Biomed., 3(9): 678-681.

Golkar, Z., O. Bagasra, and D.G. Pace. 2014. Bacteriophage therapy: a potential solution for the antibiotic resistance crisis. J. Infect. Dev. Count, 8(2): 129-136.

Gregory, R.I., T.P. Chendrimada, N. Cooch and R. Shiekhattar. 2005. Human RISC couples microRNA biogenesis and posttranscriptional gene silencing. Cell, 123(4), 631-640.

Hudson, J.A., C. Billington, A.J. Cornelius, T. Wilson, S.L.W. On. A Premaratne and NJ King, 2013. Use of a bacteriophage to inactivate
Escherichia coli O157: H7 on beef. $J$. Food microbial., 36(1): 14-21.

Jin, Y., S.M. Sdao, J.A. Dover, N.B. Porcek, C.M. Knobler, W.M. Gelbart and K.N. Parent. 2015. Bacteriophage P22 ejects all of its internal proteins before its genome. J Virol., 485: 128-134.

Khan, A.A., C.D. Melvin and E.B. Dagdag. 2007. Identification and molecular characterization of Salmonella spp. from unpasteurized orange juices and identification of new serotype Salmonella strain S. enterica serovar Tempe. J. Food microbio., 24(5): 539543.

Kumar, R., P.K. Surendran and N. Thampuran. 2009. Detection and characterization of virulence factors in lactose positive and lactose negative Salmonella serovars isolated from seafood. J. Food Control, 20(4): 376380.

Levinson, W. 2010. Review of medical microbiology and immunology. $J$. Med. Micro., 25: 85-93.

Mmolawa, P.T., R. Willmore, C.J. Thomas and M.W. Heuzenroeder. 2002. Temperate phages in Salmonella enterica serovar Typhimurium: implications for epidemiology. Int. J. med. Microbial., 291(8): 633-644.

Nesa, M.K., M.S.R. Khan and M. Alam. 2012. Isolation, identification and characterization of Salmonellaserovars from diarrhoeic stool samples of human. Bangl. J. Vet. Med., 9(1): 8593.

Özkalp, B,. 2012. Isolation and Identification of Salmonellas from Different Samples. InTech., 978-953.

Panagou, E.Z., G.J.E. Nychas and J.N. Sofos. 2013. Types of traditional Greek foods and their safety. Food Control, 29(1): 32-41.

Prescot, L.M., P. John and D.A. Harley. 2005. Microbiology. New York: 
McGraw Hill International Edition Publishing, 372-384.

Rabsch, W., H.L. Andrews, R.A. Kingsley, R. Prager, H. Tschäpe, L.G. Adams and A.J. Bäumler. 2002. Salmonella enterica serotype Typhimurium and its host-adapted variants. J. Infec. Immun., 070(5): 2249-2255.

Rahaman, M.T., M. Rahman, M.B. Rahman, M.F.R. Khan, M.L. Hossen, M.S. Parvej and S. Ahmed. 2014. Poultry Salmonella Specific Bacteriophage Isolation and Characterization. Bangl. J. Vet. Med., 12(2): 107-114.

Salam, F., and I.E. Tothill. 2009. Detection of Salmonella typhimurium using an electrochemical immunosensor. Biosensors and Bioelectronics, 24(8): 2630-2636.

Salmonella Typhimurium infections associated with peanut products. New England J. Med., 365(7): 601-
610.

Singleton, P. 1992. Bacteria in biology, biotechnology and medicine. John Wiley and Sons Ltd Publishing England, 237-249.

Sulakvelidze, A., Z. Alavidze, G.J. Morris. 2001. Antimicrob. Agents Chemother. J. Infect. Dev. Count, 45: 649-659.

Tan, G.H., M.S. Nordin and A.B. Napsiah. 2008. Isolation and characterization of lytic bacteriophages from sewage water. J. Trop. Agri. Fd. Sc., 36(2).

Wang, L. 2016. Development of a Sensitive Aptamer-based PCR Method with Magnetic Immunoseparation for Detection of Salmonella Typhimurium in Poultry Products. J. Microbio. Immun., 43(2): 916-920.

Willams, R.E. and J.E. Rippon. 1952. Bacteriophage typing of $S$. typhimurium. J. Hyg. Camb., 44: 105108.

\section{How to cite this article:}

Adeela Iqbal, M. Shafi Hasni, Sajjad-ur-Rahman, Rizwan Aslam and Kasib Khan. 2016. Preparation and Evaluation of Bacteriophage Lysate Specific for Salmonella typhimurium. Int.J.Curr.Microbiol.App.Sci. 5(11): 828-835. doi: http://dx.doi.org/10.20546/ijcmas.2016.511.094 